\title{
The near future in "rollerball" dystopian movie: fictional generative themes to stimulate sociological imagination within Physical Education and sports studies
}

\author{
José-Ignacio Barbero-González* \\ Hugo Rodríguez-Campazas ${ }^{* *}$
}

\begin{abstract}
Cinema is a powerful device of public pedagogy whose potential is to a great extent neglected by the educational system. In this context, this paper illustrates how sport-related films (Rollerball) may be used pedagogically to stimulate the exercise of the sociological imagination within PE/Sports studies. To do so, we focus on a few concept/ images with generative power to encourage a dialogical approach to a bunch of significant topics related to culture, ideology, pedagogy and sport. Our underlying premise is that nontraditional texts constitute a useful tool for teaching social theory to an 'audience' much more prone to physical activity than theoretical practice.
\end{abstract}

Key words: Sports. Sports. motion pictures. Rollerball. imagination.

\section{INTRODUCTION}

Over the last decades, we have seen an increasing use of cinema and other nontraditional texts as research sources and tools for teaching social theory in the broad field of social studies (PRENDERGAST, 1986; CASTELLANO; DEANGELIS; CLARK-IBAÑEZ, 2008; WEBER, 2010; GARCÍA, 2010; SUTHERNLAND; FELTEY, 2010) and in the sub discipline of sociology of Physical Education/sports (DUNCAN; NOLAN;

\footnotetext{
'Didáctica de la Expresión Musical, Plástica y Corporal. Facultad de Educación. Universidad de Valladolid, Segovia, España. E-mail: jigna@mpc.uva.es

"Didáctica de la Expresión Musical, Plástica y Corporal. Facultad de Educación Universidad de Valladolid, Segovia, España. E-mail: hugorc@mpc.uva.es
} 
WOOD, 2002; PEARSON; CURTIS; HANEY; ZHANG, 2003; BEYERBACH, 2005; MCCULLICK; BELCHER; HARDIN; HARDIN, 2003; POULTON; RODERICK; 2008; GALAK, 2009; LINDNER, 2009; BARBERO, 2011; BARBERO; RODRÍGUEZ, 2010, 2012). Along these lines, this essay has been conceived as a pedagogical proposal about the use of sports movies to introduce some sociological imagination in the context of Physical Education/ Sports studies with little sociological inputs.

Although there is a certain consensus about what a sports movie is (a film centrally focused on a sporting event, occasion or participant), the status of the sports movie genre remains somehow elusive (JONES, 2008). In a broader study mapping the field, we have delimited a space inhabited by a small bunch of films whose plots revolve around certain games played somewhere in a time still to come. These films are usually labelled as "science fiction" (SF from now on). Given the problems surrounding this concept, especially with regard to the nature of science in the plausibility of the imagined story (BASSA; FREIXAS, 1993, p. 11-31), we prefer the descriptive term "futurist".

As the action of these sports movies takes place in a near or remote future, the tales recreate utopias in the spectators' imaginary. Although it might be better to say "dystopias", that is, critical representations that,

[...] unlike utopias, offer not a hopeful vision of what ought to be but an angry or despairing picture of where we are said to be headed -or perhaps (though we may not know it) where we already are. (HALPER; MUZZIO, 2007, p. 381).

Taking into account the influential role played by sports films as content and form of public pedagogy (GIROUX, 2002; 2011) in our post-post spectacular mass-mediated society (VARGAS LLOSA, 2012), we summarize our pedagogical usage of "Rollerball" (1975) to enhance students' understanding of the social nature and functions of sport in society. 


\section{Objectives}

Physical education and Sports students:

$[\ldots]$ often define themselves, and are defined by others, as "jocks" and members of a "jock culture". This culture has been associated with the production and maintenance of hegemonic forms of heterosexual masculinity via a range of social practices and ideological formations that celebrates mesomorphy, anti-intellectualism, sexism, homophobia, and competitiveness (SPARKES; BROWN; PARTINGTON, 2010, p. 337).

As the academic predisposition is not a distinctive feature of Physical education and Sports students, the underlying premise of this paper is that sports movies (and other nontraditional texts) have a great potential for teaching social theory to youngsters much more interested in physical activities than in theoretical practice. In this context, two complementary sets of questions guide our work.

The first relates to the theory and practice of teaching: how to integrate (fragments of) sports movies within our pedagogical discourse; do they contribute to arouse our students' curiosity upon the concept/images selected; do they stimulate a more dialogical approach to knowledge; what's the potential of this kind of work within PE/sports studies with little sociological inputs.

The second refers to sports and the social context: how are they constructed; what are their features; what kind of society is recreated in "Rollerball"; which role does the game play in the near future's society.

\section{THEORETICAL PREMISES}

In summary, our underlying theoretical assumptions are the following:

To integrate the movie within our pedagogical discourse, we rely upon Freire's "generative themes" (for us, "generative concept/ 
images"). Rephrasing this author (FREIRE, 2005, p. 109), "in contrast with the (usual) antidialogical and non-communicative "deposits" of "banking education", we try to connect selected movie fragments with real existential situations to stimulate the awakening of critical consciousness through a dialogical approach to knowledge. Therefore, generative themes aren't mere topics for class discussion; they are chosen because of its (attributed) potential to enable subjects involved (teachers and students) to decode hegemonic culture in our field.

In relation to sport and the social context, we share Elias' idea (1986, p. 19) that knowledge about sport is knowledge about society, and vice versa. This is so because sport is a social construction that reflects and recreates the disputes and power relations between groups and classes in the wider context. In this sense, taking into account Jewison's trajectory (see below), we think that the director used this sports movie to tell the audience a cautionary tale about society and that "Rollerball" contains critical generative concept/ images that may enhance the understanding of the economic, political and cultural context in which the game is embedded.

With reference to the kind of text (fiction movie) selected, we consider that cinema narrative explanations may be as valid as others, including academic texts, because, whatever the means of expression (art or science), author's consciousness develops or challenges the dominant episteme that establishes the "[...] condition of possibility" for knowledge in a given time (Foucault, 1988, p. 7). Following Bergala (2007, p. 111-125), we work with "selected fragments put in relation". Each fragment is an autonomous tale with its own generative potential and life. As 'fictions', movies can be placed along the line that goes from the very fictional, at one end, to the very realistic, at the other. Here, the arguments about the validity criteria for qualitative research (versus positive science) can be applied to cinema (MCMAHON, 2001; SPARKES, 2002). In this respect, the comparison between texts of different status published at the same time may throw up surprising conclusions concerning, first, the similarities between their explanations and, second, the cinematic anticipation of issues 
neglected by scholars (ZAPLANA, 2005; BARBERO; RODRÍGUEZ, 2010, 2012). Whatever the case, movies constitute only a part of our readings.

Finally, why a movie dystopia? "Rollerball" appeared in 1975; at that time, the dystopian genre was well-established: the foundational title of the SF genre, Fritz Lang's Metropolis, 1927, is a dystopian story. Negative utopias emerged, Núñez says (1986, p. 122), as an important instrument of the critical mind of the last century and, Halper and Muzzio argue (2007), "[...] perhaps the most powerful current format for dystopian discourse is the movies." So, we've chosen this film because of its potential as a critical view of sport and society.

\section{Methodological nOtes}

This paper results mostly from the content analysis of "Rollerball". Our aim was to extract fragments with (attributed) potential as generative concept/images, having in mind its integration within our teaching practice.

Content analysis consists on the application of different interpretive procedures, quantitative and qualitative, that allow the researcher to extract valid inferences related to a particular context (KRIPPENDORFF, 2004 PIÑUEL, 2002; NEUENDORF, 2002). We followed usual stages (BARDIN, 2002).

i) Pre-analysis, where we considered a small bunch (18) of dystopian sports movies, most of them dispensable. We spent eleven weeks viewing the films without sharing information about them. The pre-analysis gave us a global idea of this universe, it determined our election of "Rollerball" and it helped us to establish preliminary categories to make sense of the data.

ii) Our choice of "Rollerball". To start with, we graded it high in terms of its quality as a film; leaving that aside, it's the genre's most powerful dystopia; the game (structure, rules, players, etc.) seems 
real; as the recreated near future is just round the corner, connections with our present are easy to establish; and because when considering possible generative concept/images, we soon detected that it had a great potential for our purposes.

iii) Preliminary analysis of "Rollerball". To gain insight into a 'text' it's necessary to consider its conditions of possibility, so we looked at the origins of the film and director's motivations. (See section: the film in context.)

iv) Analysis in depth of "Rollerball". Having in mind our praxis as teachers within Physical education/sports studies, we read into the movie in order to choose the categories and "concept/images" (CABRERA, 2008, p. 17-32) with generative potential. We carried out this work independently, filling out a semi-structured data sheet designed from the pre-analysis. Then we compared emerging themes and decided to focus only on those we agreed that our notes were similar. Finally, we depicted two main spheres, one referred to the characterization of future society, the other focused on the features of the game. Data (ideas, shades, redundancy, times...) were organized along the categories listed in the section Reading "Rollerball".

v) The construction of a story. Drawing on previous categories and ideas, we devised a story (teachers communicate through stories) compounded by those fragments that, in our opinion, had more potential to function as generative concept/images. The story headings were those that structure later section 7 .

vi) The telling of the story. We used it first in a seminar with a group of colleagues (university teachers, men and women who work in different contexts, most of them Spaniards) worried about their own teaching practice: I teach future teachers how to teach, but how do I teach? Due to previous experiences, these people, most of them with little sociological background, weren't very keen on sociology (an obscure and dense discipline, they say, whose practitioners enjoy making it even more dense and obscure). This predisposition is also quite common among Physical education/Sports 
students. Some participants' comments, elicited by a post-lecture semi-structured questionnaire and researchers' notes, have been used in the closing section of this paper.

vii) The writing of the story. We don't approach it as the final task, but as a significant part of the method of inquiry (RICHARDSON, 2000, p. 923). We are convinced that research is a much dirtier and uneven process than it's usually suggested. For us, these phases are simultaneous and related stages, rather than consecutive and independent. Furthermore, there isn't one only writing but several writings; there isn't one only story but several stories for different purposes.

\section{THE FILM IN CONTEXT}

\subsection{THE PLOT}

In case the reader hasn't seen the film, this tagline summarises what the movie is about: "In the not-too-distant future, wars will no longer exist, but there will be rollerball" (HARRISON, 2010, p. 82).

It's the year 2018. Following a period of wars, the world is now ruled by the anonymous executives of a few multinational corporations that have replaced national states. Theoretically, all problems have been solved and corporate government provides all needed goods. In this peaceful world, citizens are comfortably numb and anesthetized by the violent sport of rollerball that diverts their attention and, as a safety valve, it channels their hostile impulses. Teams are owned by the corporations. The superstar of the game is Jonathan $\mathrm{E}$, the veteran captain of the Houston team. When corporate tycoons feel that the individual role of this idol is becoming a grave threat for the system, they ask him to retire. In these circumstances, Jonathan E challenges the status quo asking how decisions are made. In summary, as Williams says (2006, p. 42): "Rollerball endures a provocative indictment not only of the rise of corporate power at the cost of personal freedoms, but also of our fascination with ritualized violence". 


\subsection{THE AUTHORS}

Norman Jewison is probably the best known, versatile and awarded Canadian director and producer. He conceives cinema not just as mere entertainment but as a means to educate the audience. In this sense, his films ooze a moral intention.

Jewison's filmography focuses on a wide range of social issues, e.g., racism (In the heat of the night, 1967; A Soldier's Story, 1984; The Hurricane, 1999), judiciary corruption (And justice for all, 1979), religion (Jesus Christ Superstar, 1973; Agnes of God, 1985), Cold War paranoia (The Russians are Coming, The Russians Are Coming, 1966), the Vietnam war (In country, 1989)... and sports violence (Rollerball, 1975).

Jewison paid attention to sports in two occasions; first, in Rollerball, he imagined the near future; second, in The Hurricane, he recalled the near past: [...] Here comes the story of the Hurricane | the man the authorities came to blame | for something that he never done $\mid$ put in a prison cell, but one time he could have been $\mid$ the Champion of the World... (BOB DYLAN: Hurricane, 1999)

The screenplay is based on a short story (Roller Ball Murder) published in September 1973. According to its author (HARRISON, 2010, p. 79), it was an experimental writing that probably no editor or even one's best friend was ever going to read. He mailed it off and Esquire bought it. The seeds of the film were already there:

\footnotetext{
On the conviction that almost everyone in America loves violent sports I concocted a story about a game played by corporate teams in which a futuristic gladiator tries to figure out how things became so complicated. I knew it was a brand of science fiction, futurism... (HARRISON, 2010, p. 80).
}

We have then two authors of the same generation (Jewison was born in 1926 and Harrison in 1933), educators and intellectuals (one through cinema, the other in the university), who share similar concerns. As men of culture, they couldn't be outside the problematic that shocked USA citizens during the 60s and 70s (the Cold War, the 
movements pro civil rights, the Vietnam War, the economic crisis, Watergate ...). Simultaneously, in Europe, the Prague Spring and May 68 moved public consciences and emerged as symbols of the ongoing and forthcoming changes. In this context, during the 1960s and 1970s, conflict and critical theories erased the hegemonic position of structural functionalism and, according to Held (1980, p. 14), critical theory caught the imagination of students and intellectuals all around the world and cheap editions of the works of Marcuse and the other Frankfurtians occupied the bedside tables of the members of the New Left.

In conclusion, "Rollerball" outlines socio-cultural issues in American society and purveys values and mores (PEARSON; CURTIS; HANEY; ZHANG, 2003, p. 145). As one contemporary reviewer asserted, facts were stranger than fiction: "Rollerball, as demonstrated in the movie, looks nowhere near as brutal as... the Indianapolis 500 (CANBY, 1975)

\section{Reading "rollerball"}

Given space limits, we only list the main themes and sub-themes that constituted the basis for the configuration of the concept/images.

"Characterization of future society

*The present/near future

*Political system

*Social classes - the distribution of wealth and privileges

*Women, family and race

*The media

*Drug dependency

*Abolition of books and History

*Political participation and resistance

"Game's characterization 
*A hybrid discipline

*A real game

*Game's structural simplicity

*An institutionalized practice

*The spectacle of violence as a safety valve

* Social role of the champions

The selection of these themes and subthemes and data gathered in them were compared with director's commentary while revisiting the making of the film (JEWISON, 2000).

\section{DEVISING A STORY FOR PE AND SPORTS SCIENCES STUDENTS}

Drawing on the previous ideas, we present now the sociological issues and the related generative concept/images selected to construct our story. Given the dominant discourse of "Rollerball", issuesfragments-and-concept/images focus on topics referred to social control and sport (that is, culture).

\subsection{SOCIAL CONSTRAINS VS ACTION}

The dualism structure-agency is a central debate within the sociological imagination and it's one of the most fundamental causes of sociologists' headaches.

According to some reviews, Rolleball's storyline moves precisely around such opposition. On the one side, corporate society has solved all of mankind's problems but it demands of everyone not to interfere with management decisions, that is, luxury comfort buys freedom and participation in the public affairs: "We're livin' good, you know we are", a naïve sportsman concludes. On the other, we see the awakening of Jonathan E consciousness and his determination to challenge the system. 
So this generative concept/image (the representation of this opposition in the film) serves to introduce the ideas of social structure and agency, and to expand on the different interpretations of the relations between those two key concepts: determination by the social structure, emphasis on social action and the overcoming of the dualism.

\subsection{GLOBALIZATION OR A GLOBAL CIRCUS?}

In the leading article of the monograph "Le sport c'est la guerre", Ramonet (1996, p.7) says: "Can we wonder if this televised culture is not turning into the dominant culture of the planet? What do we have culturally in common with the antipodes citizens? Possibly Maradona"

A few years later, Giddens (2002, p. 6) begins the chapter "Globalization" with this paragraph:

A friend of mine studies village life in central Africa. A few years ago, she paid her first visit to a remote area where she was to carry out her fieldwork. The day she arrived, she was invited to a local home for an evening's entertainment. She expected to find out about the traditional pastimes of this isolated community. Instead, the occasion turned out to be a viewing of "Basic Instinct" on video. The film at that point hadn't even reached the cinemas in London, where we lived.

"Globalization", Giddens continues (2002, p. 7), is a term scarcely used in the $80 \mathrm{~s}$, neither by the academics nor in everyday language. Nevertheless, it's one of the central concept/images of "Rollerball" and, hence, the movie provides us with a generative resource to introduce and debate the concept.

Within this alienating view of globalization, there is also the opportunity to introduce the issue of the social functions played by the sports superstars because Jonathan E is today's Messi, Nadal, Federer, etc. So questions may emerge about how sports and superstars distract the masses diverting their attention from important issues concerning their conditions of existence. 
This may lead us to consider negative concept of ideology as 'false consciousness' that distorts the perception of reality and to the slogan, rephrasing Marx, that the secular religion of sport is the new opiate of the masses. As Jhally suggests (1989, p. 70), the left has always criticized the use of sports to narcotize the population and the priority given to sports by media coverage.

\subsection{Sport as an Ideological State Apparatus}

Here we expand previous point. Although we take the expression "Ideological State Apparatus" from Althusser's essay (1971), we use it here in a rather loose sense to reflect upon the connections between sport, culture, ideology, pedagogy and social consensus in our mass-mediated society. The sociological imagination offers stronger and weaker explanations of such relations. Among the first, it's Althusser's idea that ideology reflects the infrastructure and that the ideological State apparatuses constitute the subjects trough ideology. Within this framework subjects are reduced to mere puppets and there's little space for agency. Among the second, it's an opportunity to introduce gramscian stimulant concept of "hegemony", which emphasizes that consciousness is not a passive reflection of the economic infrastructure, that domination is not exerted only by force but also by ideas and that, consistently, consent is often spontaneous. Furthermore, hegemony is unstable:

A lived hegemony is always a process. It is not, except analytically, a system or a structure. It is a realized complex of experiences, relationships and activities, with specific and changing pressures and limits. (...) It has continually to be renewed, recreated, defended, and modified. It is also continually resisted, limited, altered, challenged... (WILLIAMS, 1977, p. 112)

In this respect, the generative concept/image of the film is the obvious symbiosis between Multivision and the game. As Candy suggested in 1975, the movie could be seen as a satire of our national preoccupation with televised professional sports. A trend that has since then grown on a global scale. 


\subsection{The CivilizIng Process}

Rollerball is a brutal sport (SENN, 2006), so the film provides many scenes that may be used as generative concept/images to introduce Elias's figurational model of the civilizing process. In short, the central problem addressed by this author is the complex relationship between sociogenesis and psychogenesis, that is, the connections among the individual personality in a given time and the broader structure of society (e.g., his brief study of Mozart, sociology of a genius; ELIAS, 1991).

The civilizing process is a slow long term process of selfcontrol's apprenticeship, of internalization of an economy of the emotions that makes external social constraints less necessary. Elias took the term from Erasmus of Rotterdam's brief treatise (1985) "De civilitate morum puerilium", a 16th century bestseller whose purpose was the education of the Modern Prince. This handbook of good manners focuses on bodily functions, self-control and privacy and constitutes a distinctive landmark towards the new modern individual human being.

Ulterior changes in the structure of European society (economic development, the expansion of urban living, the increasing division of labour and interdependencies among social groups, the extension of state power monopolizing the use of violence, etc.) correspond to particular forms of the individual personality. In this context, both the "sportivization" of popular games and the "parliamentarization" of governmental procedures reflect the fact that dominant groups were prepared to settle down conflicts by pacific means. As Elias (1986, p. 40) explains:

It was simply that the same class of people who participated in the pacification and greater regularization of factional contests in Parliament were instrumental in the greater pacification and regularization of their pastimes.

However, the lowering of the threshold of repugnance towards blood and public cruelty implied by the civilizing process may be 
challenged by the brutal, explicit and purposeful violence of Rollerball's near future. This can lead the debates towards both the civilizing and the de-civilizing (and de-sportivizing) processes.

\subsection{GLORIFYING INDIVIDUALISM}

The generative concept/image for this issue is the main character of the film, Jonathan E, the veteran game's superstar, the leader of the team and the only one with courage to challenge (and defeat) the system. The final scenes of the movie (an injured Jonathan E skating in the ring dodging the remains of the battle, adjusting his pace to the roars of the devoted masses, raising his fist as a victory sign accompanied by the first chords of the Toccata and Fugue in D minor) weave a conclusive praise of individualism.

Over the last three decades, Physical Education/Sports literature has uncovered individualism as the dominant ideology in Sports (HARGREAVES, 1986). One aspect of this ideology is its connection to winning or, as in the film, to the cult of winning. In this sense, the crux of the matter is the tendency to naturalize competition as the normal (natural) relationship among people. As Tinning says (1990, p. 13):

The commonsense view of the place of competition and winning in $\mathrm{PE}$ is that competition is a natural part of society, and those who succeed in our society do so because they possess ability and apply themselves to succeed; and that PE should contribute to this 'natural way of things'. The fact that it is seen as 'natural' is evidence of the ideological work of individualism. As ideology, it becomes the 'commonsense' view.

\subsection{INTRODUCING CRITICAL THINKING}

Cinema provides PE students and researchers with many interesting movies to stimulate conflict and critical approaches to a field that it's usually regarded as unproblematic and distant from the economic/cultural dilemmas that weave and divide society. As we have explained, Rollerball is a political statement with an educational 
and moral purpose. Although this intention is detectable in other films, the emergence of Rollerball can help to contextualize the shaping of critical thinking within our field of knowledge.

Produced in 1975 and inspired on Harrison's experimental short story "Roller ball murder" (1973), it reflects the critical views toward Physical Education and sports that crystallized within the academic literature during the late 60s and early 70s (RIGAUER, 1969; VINNAI, 1970; BERTHAUD; BROHM, 1972; BROHM, 1975; 1976). These authors share a Marxist approach to sports and society. A perspective perhaps mediated by Gramsci, the Frankfurtians, Althusser and other thinkers of their previous generation who emphasized the role of culture, ideology and pedagogy.

In short, this movie can facilitate the anchoring of the basic concepts of an approach that links sports to the economic structure, cultural inequalities and power relations.

\section{FINAL COMMENTS FROM THE STORY TOLD}

As we explained in the methodological notes section, these final comments have been extracted from our telling of the story to a group of PE/Sport sciences teachers. Most of the dialog moved around the dual aim of this paper: sport in the social context and the praxis of teaching.

i) Despite their negative predisposition towards sociology, people found our 'lecture' pleasant, instructive, illuminating and dialogical. Leaving aside such generic and affable comments, it's obvious that selected movie fragments served to attract participants' attention upon the related concepts/images. Furthermore, the dialog brought about an unforeseen issue: body imagery and body representations of characters, actions, situations, feelings, power relations, etc. So, the movie opened up the way for the inclusion of embodied narratives in our pedagogical discourse.

ii) Straightforward relations were established between the depicted corporate society and some of our public debates in these 
times of crisis: the increasing discredit of politicians; the attacks upon social rights; the power of the multinationals and financial organizations; the threat of intervention (the arrival of the men in black) and the rise of technocracy; in short, rephrasing Jonathan E, how political decisions are taken in our country, in the European Union, in...

iii) The most lively discussion emerged around Elias's concept of the civilizing processes. Despite the emphasis on the idea of slow-long-term processes which therefore takes into account the possibility that, in a given context or circumstances, society could move backwards (de-civilizing), one participant was quite reluctant to accept the model.

iv) Media, sports superstars, hegemonic culture and globalization was a topic that generated great consensus. In this respect, one participant posed an intriguing and provocative question: if totalitarian regimes use(d) sports to divert people's attention from social issues, she said, do we live in a democracy? ... because it never has been in Spain more tv-radio sports-programs, sport-channels, sport-etc. (...) than nowadays!

v) Movies, fragments and still pictures, if properly selected, nourish dialog. However, one of the dangers of this dynamics is to keep ourselves at this level (teacher's satisfaction because of students' mere participation) forgetting the purposes of the process. The group named this issue as the need to move out from the anecdote to gain access to more universal codes.

vi) Nobody questioned the use of fiction movies as a pedagogical tool to stimulate students' interest upon particular issues. Furthermore, participants agreed on the potential of nontraditional text to develop, as Tinning says (2001, p. 49), pupil's capacities to critically engage the messages about physical activity and the body that are ubiquitous in popular culture. Nevertheless, although they were in favor of any kind of artifice that may facilitate access to knowledge, there was some debate about the nature of the knowledge gained through different means. 
vii) Finally, although the purpose of this paper wasn't to reach generalisable conclusions, our overall appreciation is that the story we devised with the selected concept/images generated a dialogical approach to knowledge that gave participants a real opportunity to share ideas and experiences about sport, society, cinema and pedagogy. In other words, this particular dystopian movie serves to stimulate connections between fiction and everyday life, between the personal and the social, and, in doing so, it constitutes an opportunity for the empowering exercise of the sociological imagination. 
El inmediato futuro de la película distópica "rollerball": temas generativos para estimular la imaginación sociológica en los estudios de ciencias de la Educación Física y el deporte

Resumen: El cine es un poderoso dispositivo de pedagogía pública cuyo potencial es ignorado por el sistema educativo. En este contexto, este artículo muestra el modo en que una película deportiva (Rollerball) puede servir para estimular el ejercicio de la imaginación sociológica en los estudios de EF y Deporte. Para ello, nos centramos en un reducido número de conceptos/imágenes seleccionados por su capacidad para generar una praxis pedagógica dialógica en torno a un pequeño grupo de significativos asuntos relativos a la cultura, la ideología, la pedagogía y el deporte. Nuestra premisa tácita es que los textos no-tradicionales son una herramienta muy útil para enseñar teoría social a una 'audiencia' que se muestra mucho más predispuesta a la práctica de la actividad física que a la práctica teórica.

Palabras clave: Deportes. Cine. Rollerball. imaginación

O futuro imediato do filme distópico "rollerball": temas geradores para estimular a imaginação sociológica nos estudos de ciências da Educação Física e esportes

Resumo: O cinema é um poderoso dispositivo de pedagogia pública cujo potencial é ignorado pelo sistema educativo. Neste contexto, este artigo apresenta como um filme sobre esportes (Rollerball) pode servir para estimular o exercício da imaginação sociológica nos estudos de Educação Física e Esportes. Para isso, centramo-nos num reduzido número de conceitos/imagens seleccionados pela sua capacidade para gerar uma praxis pedagógica dialógica em torno de um pequeno grupo de assuntos significativos relativos à cultura, à ideología, à pedagogía e ao esporte. A nossa premissa tácita é que os textos não tradicionais são uma ferramenta muito útil para ensinar teoria social a uma "audiência" que se apresenta muito mais predisposta à prática da atividade física que à prática teórica.

Palavras chave: esportes. Cinema. Rollerball. imaginação 


\section{REFERENCES}

AGNES of God. Columbia Pictures, $101 \mathrm{~min}, 1985$.

ALTHUSSER, Louis. Ideology and Ideological State Apparatuses (Notes towards an Investigation). In Lenin and philosophy, and other essays. London: MRP, 1971. p. $127-186$.

AND JUSTICE for all. Columbia Pictures, $117 \mathrm{~min}, 1979$.

BARBERO, José Ignacio. Ficciones en torno al deporte en tiempo de crisis. Cultura, Ciencia y Deporte, Murcia, v. 6, n. 16, p., 65-71, 2011.

BARBERO, José Ignacio; RODRÍGUEZ, Hugo. Significados y funciones del deporte en la vida "colegial". Análisis de tres películas de cine mudo. Ágora para la Educación Física y el Deporte, Valladolid, v. 12, n. 1, p. 49-74, 2010.

BARDIN, Laurence. Análisis de contenido. Madrid: Akal, 2002.

BASSA, Joan; FREIXAS, Ramón. El cine de ciencia-ficción: Una aproximación. Barcelona: Paidós, 1993.

BERGALA, Alain. La hipótesis del cine: pequeño tratado sobre la transmisión del cine en la escuela y fuera de ella. Barcelona: Laertes, 2007.

BERTHAUD, Ginette; BROHM, Jean-Marie. Sport, culture et re?pression. Paris: Maspero, 1972.

BEYERBACH, Barbara. The social foundations classroom. Themes in Sixty Years of Teachers in Film: Fast Times, Dangerous Minds, Stand on Me. Educational Studies: A Journal of the American Educational Studies Association, Philadelphia, v. 37, n. 3, p. 267-285, 2005.

BROHM, Jean-Marie. Corps et politique. Paris: Delarge, 1975.

BROHM, Jean-Marie. Sociologie politique du sport. Paris: Delarge, 1976.

CABRERA, Julio. Cine: 100 años de filosofía. Barcelona: Gedisa, 2008.

CANBY, Vincent. Futuristic World of 'Rollerball'. New York Times. 26th June 1975. (http://movies.nytimes.com/movie/review?res=9A01EFDD103CE 034BC4E51DFB066838E669EDE). Acceso en : 20 out. 2010.

DUNCAN, Charles A.; NOLAN, Joe; WOOD, Ralph. See you in the movies. We hope not! The Journal of Physical Education, Recreation \& Dance, Virginia, v. 73, n. 8, p. 38-44, oct., 2002. 
EL DEPORTE a principios del siglo XX: su (re)presentación en películas de distintas épocas. Cultura y Educación, Madrid, v. 24, n. 3, p. 305-318, 2012.

ELIAS, Norbert. Introduction. In: ELIAS, N. ; DUNNING, E. Quest for Excitement: Sport and Leisure in the Civilizing Process. Oxford: Blackwell, 1986. p. 1962

ELIAS, Norbert. Mozart. Sociología de un genio. Barcelona: Península, 1991.

ERASMUS OF ROTTERDAM. De civilitate morum puerilium. Madrid: MEC, 1985 (1530).

FOUCAULT, Michael. Las palabras y las cosas: Una arqueología de las ciencias humanas. México: Siglo XXI, 1988.

FREIRE, Paulo. Pedagogy of the Oppressed. London: Continuum, 2005.

GALAK, Eduardo. El oficio del maestro de gimnasia. Una mirada de las prácticas gimnásticas a través de los Simpson. Ágora para la EF y el Deporte, Valladolid, n. 11, p. 63-78, 2009.

GARCÍA, Luis. Sociedad y cine. In: RIVAYA, B.; ZAPATERO, L. (Ed.) Los saberes y el cine. Valencia: Tirant lo Blanch, 2010. p. 377-410.

GIDDENS, Anthony. Runaway world: How globalization is reshaping our lifes. London: Profilebooks, 2002.

GIROUX, Henry A. Breaking into the movies: Film and the culture of politics. Oxford: Blackwell, 2002.

GIROUX, Henry A. Breaking into the Movies: public pedagogy and the politics of film. Policy Futures in Education, Oxford, n. 9, v. 6, p. 686-695, 2011.

HALPER, Thomas; MUZZIO, Douglas. Hobbes in the City: Urban Dystopias in American Movies. The Journal of American Culture, Malden, v. 30, n.4, p. 379390, dec. 2007.

HARGREAVES, John. Sport, power and culture: a social and historical analysis of popular sports in Britain. Cambridge: Polity Press, 1986.

HARRISON, William. Roller ball murder. Squire, Sep., 1973. (See Roller ball murder. New York: Morrow, 1974, p.77-95.)

HARRISON, William. The Mutations of Rollerball. Essays. USA: Xlibris, 2010.

HELD, David. Introduction to critical theory: Horkheimer to Habermas. Berkeley: University of California, 1980. 
The near future in "rollerball" dystopian movie: fictional...

IN COUNTRY. Warner Bros, 106 min, 1989.

IN THE HEAT of the night, Warner Bros, 109 min, 1967.

JESUS Christ Superstar. Universal Pictures, 112 min, 1973.

JEWISON, Norman (dir.). Return to the Arena: The Making of Rollerball. (Special Edition, DVD), 2000.

JEWISON, Norman. (Mentioned movies)

JHALLY, Sut. Cultural studies and the sports/media complex. In: WENNER, L.A. (Ed.) Media, sports \& society. Newbury Park: Sage, 1989. p. 70-93.

JONES, Glen. In praise of an 'invisible genre'? An ambivalent look at the fictional sports feature film, Sport in Society, Oxfordshire, v. 11, n. 2/3, p. 117-129, march/ may, 2008.

KRIPPENDORFF, Klaus. Content analysis. An introduction to its methodology. Thousand Oaks: Sage, 2004.

LINDNER, Katharina. Fighting for Subjectivity: Articulations of Physicality in Girlfight. Journal of International Women's Studies, Massachusetts, v. 10, n. 3, p. 417, march, 2009.

McCULLICK, B., BELCHER, D., HARDIN, B.; HARDIN, M. Butches, Bullies and Buffoons: Images of Physical Education Teachers in the Movies. Sport, Education and Society, Oxfordshire, v. 8, n. 1, p. 3-16, jan. 2003.

McMAHON, Jennifer. The function of fiction: the heuristic value of Homer. In IRVIN, W., CONARD, M.T.; SKOBLE, A.J. (eds). The Simpsons and philosophy: the d'oh! of Homer. Chicago: Open Court, 2001, p. 332-363.

NEUENDORF, Kimberly A. The Content Analysis Guidebook. Thousand Oaks: Sage, 2002.

NÚÑEZ, Luis. Sobre el proceso de la utopía a la distopia, Revista de estudios políticos, Madrid, n. 52, p. 111-123, jul/aug.1986.

PEARSON, Demetrius W., CURTIS, Russel L., HANEY, C. Allen; ZHANG, James J. Sport Films: Social Dimensions Over Time, 1930-1995, Journal of Sport and Social Issues, Thousand Oaks, v. 27, n. 2, p. 145-161, may 2003.

PIÑUEL, José Luis. Epistemología, metodología y técnicas del análisis de contenido. Estudios de sociolingüística, Vigo, v. 3, n. 1, p. 1-42, 2002. 
POULTON, Emma; RODERICK, Martin. Introducing sport in films, Sport in Society, Oxfordshire, v. 11, n. 2/3, 107-116, march/may, 2008.

RAMONET, Ignacio. La mort en direct. Le monde diplomatique, Paris, n. 30, p. 7, may, 1996.

RICHARDSON, Laurel. Writing. A method of inquiry. In: DENZIN, N.K.; LINCOLN, Y.S. (Eds.) Handbook of qualitative research. Thousand Oaks: Sage, 2000. p. 923948.

RIGAUER, Bero. Sport und Arbert. Frankfurt: M.: Suhrkamp, 1969.

ROLLERBALL. United Artist, 128 min, 1975.

SENN, Bryan. The sport of violence: Death race 2000 and Rollerball. In HOGAN, D.J. (Ed.) Science fiction America: essays on SF cinema. Jefferson: McFarland, 2006. p. 207-216.

A SOLDIER'S Story. Columbia Pictures, $101 \mathrm{~min}, 1984$.

SPARKES, Andrew C. Telling tales in Sport and Physical Activity. A qualitative journey. Champaign-IL-USA: Human Kinetics, 2002.

SPARKES, Andrew C., BROWN, David. H. K. \& PARTINGTON, Elizabeth. The "Jock Body" and the Social Construction of Space: The Performance and Positioning of Cultural Identity. Space and Culture, Thousand Oaks, v. 13, n. 3, p. 337-347, aug., 2010.

THE HURRICANE. Universal Pictures, 125 min, 1999.

THE RUSSIANS are Coming. MGM/UA, 120 min, 1966.

TINNING, Richard. Camisetas holgadas, Reeboks, escolarización, cultura popular y cuerpos jóvenes. Ágora para la EF y el Deporte, Valladolid, n. 1, 49-54, 2001.

TINNING, Richard. Ideology and PE. Opening the Pandera's box. Deaking: University, 1990.

VARGAS LLOSA, Mario. La civilización del espectáculo. Madrid: Alfaguara, 2012.

VINNAI, Gerhad. Fußballsport als Ideologie. Frankfurt/Main: Europäische Verlagsanstalt, 1970.

WILLIAMS, Randy. Sports cinema. 100 movies. The best of Hollywood's athletics heroes, losers, myths and misfits. New Jersey: Limelight, 2006

WILLIAMS, Raymond. Marxism and Literature. Oxford: University Press, 1977. 
The near future in "rollerball" dystopian movie: fictional...

WRIGHT MILLS, Charles. The sociological imagination. Harmondsworth: Penguin, 1970.

ZAPLANA, Andrés. Profesores en el cine. Badajoz: Diputación provincial, 2005.

Dirección postal :

Universidad de Valladolid

Facultad de Educación

Campus María Zambrano

Plaza Alto de los Leones, 1

40005-Segovia

España

Recebido em: 18.11. 2012

Aprovado em: 24.02. 2013

Movimento, Porto Alegre, v. 19, n. 03, p. 79-101, jul/set de 2013. 